\title{
Demography Factors and Faculty Members' Teaching Efficacy in Vietnamese Higher Education
}

\author{
Minh-Quang Duong ${ }^{1}$ (Corresponding author), \\ E-mail: duongminhquang@hcmussh.edu.vn \\ Thuy-An Nguyen ${ }^{2}$, Hong-Phan Nguyen ${ }^{3}$ \\ ${ }^{1,2,3}$ University of Social Sciences and Humanities \\ Vietnam National University of Ho Chi Minh City \\ 10-12 Dinh Tien Hoang Street, District 1, Ho Chi Minh City, Vietnam
}

Received: Dec. 4, 2016 Accepted: Dec. 20, 2016 Published: February 1, 2017

doi:10.5296/jse.v7i1.10397 URL: http://dx.doi.org/10.5296/jse.v7i1.10397

\begin{abstract}
Faculty members' perceptions of teaching efficacy have a positive influence on teaching performance and students' learning achievement. Even less is known about university faculty teaching efficacy in the countries like Vietnam. This study was to investigate university faculties' perceptions of teaching efficacy in Vietnamese higher education and their relation to faculty members' demography. A questionnaire measuring 27 items of six factors of teaching efficacy was distributed to 124 university faculty members in Vietnam. The results showed that the most faculty members were highly measured with their teaching efficacy. Different factors of demography have different influences towards teaching efficacy. Almost demography factors, except length of employment factor, of gender, marital status, age groups, academic rank, and educational attainment were significant differences in faculty teaching efficacy. The study's implications for university management are also discussed.
\end{abstract}

Keywords: Teaching efficacy, demography, Vietnamese higher education, faculty member. 


\section{Introduction}

Most higher education institutions pursue a mission of teaching, research and community service. Teaching is one of the most stressful occupations (Veldman, Tartwijk, Brekelmans \& Wubbels, 2013) due to lack of support, workload, and classroom management issues (Johnson, Cooper, Cartwright, Donald, Taylor \& Millet, 2005). In many developing countries, the teaching force is mired in bureaucracies and centralized education systems that support neither the effective performance of teachers nor their career development (VSO, 2002).

Teaching efficacy was developed in Bandura's (1997) social cognitive and self-efficacy theories which were four sources of efficacy expectation such as: mastery experience, verbal persuasion, vicarious experiences and physiological arousal. Bandura (1986, p.31) defined self-efficacy as "people's judgment of their capabilities to organize and execute courses of action required to attain designated types of performances". The research of Bandura showed that self-efficacy is a key concept of social cognitive theory which was that behavior is best understood in terms of a triadic reciprocal system-consists of three items: cognition, environment, and behavior. Cook (1998, p.14) identified that "teaching efficacy is not an observable behavior, but rather an individual belief'.

Teaching efficacy is "a judgment about capabilities to influence student engagement and learning, even among those students who may be difficult or unmotivated (Woolfolk Hoy, 2004, p.1). According to Tschannen-Moran, Woolfolk Hoy \& Hoy (1998, p. 232), teaching efficacy is considered as "teacher's belief in his or her capability to organize and execute courses of action required to successfully accomplish a specific teaching task in a particular context". The selection of positive teaching behaviors, efficacious teachers tend to have high student achievement. Goddard, Hoy and Woolfolk Hoy (2000) demonstrated that faculty teaching efficacy is related to students' academic achievement, intrinsic motivation, and learning efficacy. Ross (1994) suggested teachers with high sense of efficacy tend to be more use: 1) new approaches, 2) management techniques, 3) help students who had low academic achievement, 4) develop students' academic skills, 5) set attainable goals, and 6) persist in the face of student failure. Similarly, Woolfolk Hoy (2004) showed that teachers with a strong sense of efficacy spend more time teaching in areas, and are more open to new ideas, more willing to experiment with new methods, more committed to teaching, and tend to exhibit greater levels of planning, organization, and enthusiasm (Allinder, 1994). Tschannen-Moran, Woolfolk Hoy and Hoy (1998) identified that teacher efficacy has been connected with student achievement, student attitudes, teachers' classroom behaviors, teachers' attitudes, teacher stress and burnout, and teachers' willingness to implement innovation. Overall, teacher efficacy tends to engage in more productive, quality teacher behaviors (Ashton \& Webb, 1986; Gibson \& Dembo, 1984).

Almost studies have focused on the teachers' teaching efficacy in the elementary and secondary schools (Lin \& Gorrell, 2001; Tschannen-Moran \& Woolfolk Hoy, 2002) and little is known about the faculty teaching efficacy in higher education (Cook, 1998). However, there are some studies on effective teaching in higher education to focus on teaching conceptions. The research of Brown (1993) measured faculty teaching efficacy in five factors, 
including course design, use of media, class management, teacher-student interaction, assessment and feedback to students. Gow and Kember (1993) found nine subscales of teaching conceptions, such as: training for specific jobs, imparting information, knowledge of subjects, problem solving, motivator of students, use of media, facilitative teaching, pastoral interest, and interactive teaching. According to Mehdinezhad (2012), faculty members' self-ratings of their teaching efficacy clustered around six teaching self-efficacy factors: subject matters or content knowledge, curriculum and instruction knowledge, interaction or communication competencies, evaluation of learning or assessment, knowledge of the learning environment and implementing technology in the curriculum. In this study, we used 27 items of six factors of teaching efficacy by research of Chang, McKeachie, and Lin (2010). They included course design, instructional strategy, technology usage, class management, interpersonal interaction, and learning assessment. The faculty teaching efficacy in this study is defined by Chang et al. (2010), Tschannen-Moran \& Woolfolk Hoy (2001) as the faculty members' judgment of their capabilities in course design, instructional strategy, technology usage, classroom management, interpersonal relation, and learning assessment.

It is clear that very few studies have been conducted in the area of teaching efficacy in Vietnamese higher education sector. The findings of this study, therefore, contribute to fill in the literature gap of faculty teaching efficacy in higher education. It identifies and discusses factors in Vietnamese university faculty's teaching efficacy which contribute most to their teaching performance and students' learning achievement. The present study focuses on the following research questions: 1) What is the general level of faculty teaching efficacy in Vietnamese universities? and 2) Do any significant differences exist in the level of university faculty teaching efficacy regarding demography factors?

\section{Methodology}

\subsection{Participants}

As a result, questionnaire was distributed to 140 faculty members who were drawn from faculty members to working full-time in the University of Social Sciences and Humanities, Vietnam National University of Ho Chi Minh City (USSH-VNUHCM), and 124 questionnaires were returned for $88.6 \%$ return rate which exceeded the $30 \%$ response rate to most researchers for analysis purpose (Dillman, 2000; Malaney, 2002). All data of respondents were self-reported information which was prevalently used in higher education research (Gonyea, 2005).

Broken down by gender, the sample of this study included $39.5 \%$ males and $60.5 \%$ females. For marital status, $50.8 \%$ of respondents were single, and $49.2 \%$ were married. Faculty belongs to different age groups, respondent age distribution was $44.4 \%$ below 30 years old, $22.6 \%$ from 31 to 35 years old and $16.1 \%$ from 36 to 40 years old. For length of employment in faculties' current position, $41.9 \%$ had from 1 to 5 years and $25.8 \%$ had from 5 to 10 years. Almost of $79 \%$ whose highest degree attained from Asian countries and 13.7\% were Europe countries. Of those who responded to the survey, $50 \%$ of the respondents taught in social sciences related area and $50 \%$ in humanities. For respondent educational attainment, 16.9\% 
held bachelor's degrees, $72.6 \%$ had master's degrees, and $10.5 \%$ held doctoral degrees. Overall, $75.8 \%$ of respondents were lecturers and $17.7 \%$ of teaching assistant.

\subsection{Dependent and independent variables}

Faculty teaching efficacy identified as the dependent variable in this study. As showed in Table 1, faculty teaching efficacy was composed of 27 items which were clustered around six factors such as course design, technology usage, instructional strategy, classroom management, interpersonal relation, and learning assessment. For each item, the respondents were asked to rate academic members' level of teaching efficacy on a five-point Likert's scale ranging from 1 = "strongly disagree" to 5 = "strongly agree".

Factor analysis and internal consistency analysis (Cronbach's $\alpha$ ) were conducted to assess the validity and reliability of this constructed measurement for faculty teaching efficacy in USSH-VNUHCM. Table 1 presents that factor loading values for items designed to measure each factor were consistently large from 0.619 to 0.907 which were greater than the threshold level of 0.5 (Hair, Anderson, Tatham, \& Black, 2006), showing that the twenty-seven items of six factors were all suitable for constructing teaching efficacy. A cumulative explanation from 61.25 to 80.11 percent of this study was greater than the threshold level of 60 percent (Hair et al., 2006). The internal consistency analysis yielded Cronbach's $\alpha$ coefficient from 0.830 to 0.895 in this study higher than the threshold level of 0.6 (Hair et al., 2006) and 0.7 (Nunnally, 1978), indicating satisfactory reliability for this teaching efficacy measurement. Based on the validation of construct reliability which is concluded that research construct of teaching efficacy is reliable.

Table 1. Factor analysis of twenty-seven dimensions of six aspects of faculty teaching efficacy in the USSH-VNUHCM

\begin{tabular}{|c|c|c|c|c|}
\hline Factors & Items & $\begin{array}{l}\text { Factor } \\
\text { loadings }\end{array}$ & $\begin{array}{c}\text { Variance } \\
\text { explained } \\
(\%)\end{array}$ & $\begin{array}{c}\text { Cronbach's } \\
\boldsymbol{\alpha}\end{array}$ \\
\hline \multirow{5}{*}{$\begin{array}{l}\text { Course } \\
\text { design }\end{array}$} & Have sufficient professional ability & 0.847 & \multirow{5}{*}{70.25} & \multirow{5}{*}{0.888} \\
\hline & Establish teaching objectives & 0.873 & & \\
\hline & Select appropriate teaching material & 0.858 & & \\
\hline & Arrange appropriate timeline & 0.832 & & \\
\hline & $\begin{array}{l}\text { Prepare teaching material before } \\
\text { class sessions }\end{array}$ & 0.748 & & \\
\hline \multirow{4}{*}{$\begin{array}{l}\text { Instructional } \\
\text { strategy }\end{array}$} & Utilize effective teaching methods & 0.826 & \multirow{4}{*}{76.39} & \multirow{4}{*}{0.895} \\
\hline & Sustain students' attention & 0.889 & & \\
\hline & $\begin{array}{l}\text { Inspiring and maintaining students' } \\
\text { motivation }\end{array}$ & 0.907 & & \\
\hline & Utilize various inquiring skills & 0.872 & & \\
\hline Technology & Utilize technology to enhance & 0.865 & 62.72 & 0.848 \\
\hline
\end{tabular}


usage

teaching

Select appropriate teaching media $\quad 0.891$

Product relevant teaching media $\quad 0.762$

Employ software relevant to teaching

Operate various types of teaching apparatuses

0.780

Promote a democratic environment in class

Nurture a pleasant learning

Classroom environment management

Maintain a good relationship with students

Share personal experiences with students

Listen to students 0.858

Provide assistance to students 0.899

Interpersonal Co-assess learning results and

Relation advise students 0.884

Provide appropriate assistance to students

\subsection{3}

Utilize a variety of assessment methods 0.766

Assessment methods fit teaching objectives

Learning Provide students the opportunities assessment for exercise

Assess students with positive methods

Improve teaching from assessment results

Note: Data were analyzed with principle component analysis

Table 2 shows the correlation among six dimensions of faculty teaching efficacy including course design, technology usage, instructional strategy, classroom management, interpersonal relation, and learning assessment. The value of correlation coefficient ranges from 0.512 to 0.752 was relatively high positive correlation between factors of teaching efficacy. The relationship between instructional strategy and learning assessment $(r=0.752)$ were highest 
associated. Other significant associations are lowest found between interpersonal relation and course design $(r=0.512)$.

Table 2. The results of correlation between six aspects of faculty teaching efficacy

\begin{tabular}{lcccccc}
\hline & $\begin{array}{l}\text { Course } \\
\text { design }\end{array}$ & $\begin{array}{l}\text { Instructional } \\
\text { strategy }\end{array}$ & $\begin{array}{l}\text { Technology } \\
\text { usage }\end{array}$ & $\begin{array}{l}\text { Classroom } \\
\text { management }\end{array}$ & $\begin{array}{l}\text { Interpersonal } \\
\text { relation }\end{array}$ & $\begin{array}{l}\text { Learning } \\
\text { assessment }\end{array}$ \\
$\begin{array}{l}\text { Course } \\
\text { design }\end{array}$ & 1 & & & & \\
$\begin{array}{l}\text { Instructional } \\
\text { strategy } \\
\text { Technology }\end{array}$ & $.657^{* *}$ & 1 & & & \\
$\begin{array}{l}\text { usage } \\
\text { Classroom } \\
\text { management }\end{array}$ & $.530^{* *}$ & $.646^{* *}$ & $.742^{* *}$ & $.576^{* *}$ & 1 & \\
$\begin{array}{l}\text { Interpersonal } \\
\text { relation }\end{array}$ & $.512^{* *}$ & $.724^{* *}$ & $.555^{* *}$ & $.723^{* *}$ & 1 & \\
$\begin{array}{l}\text { Learning } \\
\text { assessment }\end{array}$ & $.723^{* *}$ & $.752^{* *}$ & $.670^{* *}$ & $.722^{* *}$ & $.722^{* *}$ & 1 \\
\hline
\end{tabular}

Note: ** Correlation is significant at the 0.01 level (2-tailed).

The independent variables of this study were demographic factors, including gender, marital status, age groups, length of employment, academic rank, national educated, and discipline.

Table 3. Coding schemes and proportions of the independent variables in this study

Demographic factors:

- Gender: $1=$ male $(39.5 \%) ; 0=$ female $(60.5 \%)$

- Marital status: $1=\operatorname{single}(50.8 \%) ; 2=$ married $(49.2 \%)$

- Age: $1=$ under 30 years $(44.4 \%) ; 2=31$ to 35 years $(22.6 \%) ; 3=36$ to 40 years $(16.1 \%) ; 4$ $=41$ to 45 years $(9.7 \%) ; 5=46$ to 50 years $(2.4 \%) ; 6=$ over 50 years $(4.8 \%)$

- Length of employment: $1=$ below one year $(5.6 \%) ; 2=1$ to 5 years $(41.9 \%) ; 3=6$ to 10 years $(25.8 \%) ; 4=11$ to 15 years $(15.3 \%) ; 5=15$ to 20 years $(4.8 \%) ; 6=$ over 20 years $(6.5 \%)$

- Academic rank: $1=$ main lecturer $(6.5 \%) ; 2=$ lecturer $(75.8 \%) ; 3=$ teaching assistant $(17.7 \%)$

- Educational attainment: 1 = doctoral degree $(10.5 \%) ; 2$ = masters' degree $(72.6 \%) ; 3=$ bachelors' degree (16.9\%) 


\subsection{Data analyses}

This study employed statistical methods of descriptive analyses, independent $t$-test and the one-way analysis of variance (ANOVA) to analyze the data. Descriptive analyses were computed to understand the general level of teaching efficacy of academic members in USSH-VNUHCM. An independent $t$-test was enabled to impact of gender, marital status, and academic discipline factors on teaching efficacy of academic members. A one-way analysis of variance was performed to test the mean differences in teaching efficacy scores across faculty members' type of age, length of employment, academic rank, educational attainment, and national educated.

\section{Results and Discussion}

\subsection{The level of teaching efficacy of faculty members in USSH-VNUHCM}

Table 4 presents the results statistical means $(M)$ and standard deviations $(S D)$ of the level as well as six aspect of faculty teaching efficacy in the USSH-VNUHCM, including course design, technology usage, instructional strategy, classroom management, interpersonal relation, and learning assessment. Results indicate that the most faculty members were highly measured with their teaching efficacy $(M=4.14, S D=0.52)$, mirroring the results of the studies by Chang, Lin, and Song (2011). The findings of Chang et al. showed that the average of the total score is 3.32 (4-point scale: $1=$ strongly disagree; $4=$ strongly agree) which could be regarded as high as measure on the scale.

For the six factors to faculty teaching efficacy in USSH-VNUHCM, the findings of Table 4 also show that faculty members were highly satisfied with course design $(M=4.36, S D=$ $0.57)$, followed by classroom management $(M=4.27, S D=0.53)$, learning assessment $(M=$ $4.19, S D=0.54)$, and instructional strategy $(M=4.14, S D=0.66)$. University faculty were least satisfied with interpersonal relation $(M=3.89, S D=0.77)$, and followed by technology usage $(M=3.96, S D=0.59)$. The results of this study were supported by researches of Chang, Lin, and Song (2011); Mehdinezhad (2012); and Norton, Richardson, Hartley, Newstead, and Mayes (2005); Paneque and Barbetta (2006). The findings of Chang et al., Norton et al., and Paneque and Barbetta demonstrated that faculty members' score highest on teaching efficacy for course design and least satisfied in instruction strategy. For course design, the finding of this study was the same results with their research. They found that university faculty members are more oriented toward knowledge transmission. However, the results of this study as opposed to their researches for instructional strategy which highly measured in this study. The research of Mehdinezhad (2012) measured teaching efficacy of faculty members in the following criteria: communication skills, assessment, subject matter, curriculum and instruction, learning environment, and implementing technology. His research shows that the respondents rated their teaching efficacy in all factors as good $(M=4.23, S D=0.65)$. The research used different approaches and instruments to measure teaching efficacy for faculty members in higher education, thus, they have different results. 
Table 4. The results of Means (M) and standard deviations (SD) of the faculty teaching efficacy level in the USSH-VNUHCM

\begin{tabular}{lccc}
\hline Factors & M & SD & Rank \\
\hline Course design & 4.36 & 0.57 & 1 \\
Instructional strategy & 4.14 & 0.66 & 4 \\
Technology usage & 3.96 & 0.59 & 5 \\
Classroom management & 4.27 & 0.53 & 2 \\
Interpersonal relation & 3.89 & 0.77 & 6 \\
Learning assessment & 4.19 & 0.54 & 3 \\
Total & $\mathbf{4 . 1 4}$ & $\mathbf{0 . 5 2}$ & \\
\hline
\end{tabular}

3.2 Comparison among faculty teaching efficacy and their demography factors

Gender and faculty teaching efficacy. Regarding the relationship in teaching efficacy between male and female faculty members in USSH-VNUHCM, Table 5 indicates that there were significant differences between the level of teaching efficacy of male and female faculty members. The ranges of scores were between $M(S D)=4.51(0.48), 4.11(0.51), 4.04(0.67)$, and $4.34(0.48)$ for female faculty and $4.13(0.61), 3.73(0.64), 3.66(0.86)$, and $3.97(0.55)$ for male. These results showed that female faculty was significantly higher than their male colleagues in course design, technology usage, interpersonal relation, and learning assessment, respectively. There were no significant differences between these two groups in instructional strategy and classroom management factors.

Table 5. The results of independent t-test between gender and faculty teaching efficacy

\begin{tabular}{lccc}
\hline & Male & Female & \multirow{2}{*}{$t$} \\
\cline { 2 - 3 } & $M(S D)$ & $M(S D)$ & \\
\hline Course design & $4.13(0.61)$ & $4.51(0.48)$ & $8.964 * *$ \\
Instructional strategy & $4.03(0.79)$ & $4.21(0.54)$ & 1.476 \\
Technology usage & $3.73(0.64)$ & $4.11(0.51)$ & $3.657^{* * *}$ \\
Classroom management & $4.17(0.54)$ & $4.34(0.52)$ & 1.664 \\
Interpersonal relation & $3.66(0.86)$ & $4.04(0.67)$ & $2.727^{* *}$ \\
Learning assessment & $3.97(0.55)$ & $4.34(0.48)$ & $3.982^{* * *}$ \\
\hline
\end{tabular}

Note. The mean difference is significant at the ${ }^{* *} p<.01$, ${ }^{* * *} p<.001$

The results of this study correspond to the results of Chang et al. (2011) and Norton et al. (2005). The research of Chang et al. showed that female faculty had more agreeable than their male counterparts in learning assessment. Similarly, Norton et al. found that female faculty felt more confident than their male colleagues in the area of learning assessment. Furthermore, these researches also indicated that female score significantly higher than male faculty in classroom management which disputed in this study. However, Mehdinezhad 
(2012) shows that there was no significant differences between faculty teaching efficacy and their gender.

Marital status and faculty teaching efficacy. In terms of marital status, Table 6 indicates that there were no significant differences between these two groups in course design and technology usage factors. The ranges of scores were between $M(S D)=4.31(0.52), 4.37$ $(0.54), 4.15(0.59)$, and $4.35(0.51)$ for female and $3.98(0.73), 4.18(0.50), 3.64(0.85)$, and $4.04(0.53)$ for male faculty members in USSH-VNUHCM. Table 6 showed that female faculty was significantly higher than their male colleagues in instructional strategy, classroom management, interpersonal relation, and learning assessment, respectively. There is yet no empirical research done about the relationship between marital status and faculty teaching efficacy in Vietnamese higher education or even in other parts of the world. The results of this study, thus, can-not be compared to results of others.

Table 6 . The results of independent t-test between marital status and faculty teaching efficacy

\begin{tabular}{lccc}
\hline & Single & Married & \multirow{2}{*}{$t$} \\
\cline { 2 - 3 } & $M(S D)$ & $M(S D)$ & \\
\hline Course design & $4.28(0.63)$ & $4.45(0.49)$ & -1.701 \\
Instructional strategy & $3.98(0.73)$ & $4.31(0.52)$ & $-2.810^{* *}$ \\
Technology usage & $3.94(0.68)$ & $3.99(0.48)$ & -0.475 \\
Classroom management & $4.18(0.50)$ & $4.37(0.54)$ & $-2.005^{* *}$ \\
Interpersonal relation & $3.64(0.85)$ & $4.15(0.59)$ & $-3.851^{* * *}$ \\
Learning assessment & $4.04(0.53)$ & $4.35(0.51)$ & $-3.262^{* * *}$ \\
\hline
\end{tabular}

Note. The mean difference is significant at the $* * p<.01, * * * p<.001$

Age groups and faculty teaching efficacy. Faculty members in USSH-VNUHCM belong to different age groups, the results of Table 7 shows that there were no significant differences among different age groups and course design, technology usage, and classroom management. The finding post hoc explained that faculty members of over 50 year-old $(M=4.41, S D=$ $0.40)$ had higher scores in instructional strategy $(p<0.05)$ than other groups. Faculty from 46 to 50 years had lower scores in interpersonal relation and learning assessment $(p<0.05)$ than others from 41 to $45(M=4.30, S D=0.61)$ and 36 to 40 years $(M=4.43, S D=0.39)$, respectively. 
Table 7. The results of ANOVA between age groups and faculty teaching efficacy

\begin{tabular}{ccccccccc}
\hline \multirow{2}{*}{ Factors } & $\begin{array}{c}\text { Below 30 } \\
(\mathrm{G} 1)\end{array}$ & $\begin{array}{c}31-35 \\
(\mathrm{G} 2)\end{array}$ & $\begin{array}{c}36-40 \\
(\mathrm{G} 3)\end{array}$ & $\begin{array}{c}41-45 \\
(\mathrm{G} 4)\end{array}$ & $\begin{array}{c}46-50 \\
(\mathrm{G} 5)\end{array}$ & $\begin{array}{c}\text { Over 50 } \\
(\mathrm{G} 6)\end{array}$ & \multirow{2}{*}{$F$} & Post hoc \\
\cline { 2 - 7 } & $M(\mathrm{SD})$ & $M(\mathrm{SD})$ & $M(\mathrm{SD})$ & $M(\mathrm{SD})$ & $M(\mathrm{SD}$ & $M(S D)$ & & \\
\hline CD & $4.21(.65)$ & $4.38(.57)$ & $4.56(.40)$ & $4.55(.42)$ & $4.40(.00)$ & $4.66(.35)$ & 1.931 & \\
IS & $3.98(.73)$ & $4.239 .62)$ & $4.37(.59)$ & $4.31(.32)$ & $3.50(.00)$ & $4.41(.40)$ & $2.317^{*}$ & G6 $>$ all \\
TU & $3.95(.67)$ & $3.99(.59)$ & $4.17(.46)$ & $3.95(.45)$ & $3.60(.00)$ & $3.56(.29)$ & 1.291 & \\
CM & $4.21(.52)$ & $4.27(.59)$ & $4.41(.57)$ & $4.40(.49)$ & $3.60(.00)$ & $4.56(.44)$ & 1.941 & \\
IR & $3.66(.85)$ & $3.97(.72)$ & $4.11(.64)$ & $4.30(.61)$ & $3.66(.00)$ & $4.16(.54)$ & $2.345^{*}$ & $\mathrm{G} 4>\mathrm{G} 5$ \\
LA & $4.07(.53)$ & $4.21(.63)$ & $4.43(.39)$ & $4.41(.49)$ & $3.60(.00)$ & $4.43(.34)$ & $2.901^{*}$ & $\mathrm{G} 3>\mathrm{G} 5$ \\
\hline
\end{tabular}

Note. CD: Course design, IS: Instructional strategy, TU: Technology usage, CM: Classroom management, IR: Interpersonal relation, LA: Learning assessment. ${ }^{*} p<.0 .5$

Length of employment and faculty teaching efficacy. As in Table 8, there were no statistical difference between these length of employment at current position and faculty teaching efficacy at the USSH-VNUHCM ( $p>0.05$ ). The results of this study were supported by Chang et al. (2011) for technology usage, classroom management, and interpersonal relation which had no significant differences in faculty teaching efficacy, however, the research of Chang et al. showed that faculty teaching efficacy in course design, instructional strategy, and learning assessment were significant differences with length of employment. His research showed that faculty with above 20 years of teaching experience has higher scores in instructional strategy and learning assessment than those with below 6 years. The research of Mehdinezhad (2012) shows that faculty members with more than 20 years of teaching experience have had good assessment skill in comparison with other groups.

Table 8. The results of ANOVA between length of employment and faculty teaching efficacy

\begin{tabular}{ccccccccc}
\hline \multirow{2}{*}{ Factors } & Below 1 & $1-5$ & $6-10$ & $11-15$ & $16-20$ & Over 20 & \multirow{2}{*}{$F$} & $\begin{array}{c}\text { Post } \\
\text { hoc }\end{array}$ \\
\cline { 2 - 7 } & $M(S D)$ & $M(S D)$ & $M(S D)$ & $M(S D)$ & $M(S D$ & $M(S D)$ & & hoc \\
\hline CD & $4.28(.53)$ & $4.20(.69)$ & $4.48(.42)$ & $4.39(.40)$ & $4.66(.45)$ & $4.72(.32)$ & 2.282 & \\
IS & $4.25(.35)$ & $4.03(.82)$ & $4.27(.53)$ & $4.01(.54)$ & $4.37(.44)$ & $4.37(.38)$ & 1.018 & \\
TU & $4.03(.63)$ & $3.99(.71)$ & $3.97(.48)$ & $4.07(.46)$ & $3.80(.55)$ & $3.57(.41)$ & 0.963 & \\
CM & $4.28(.53)$ & $4.25(.55)$ & $4.40(.54)$ & $4.07(.43)$ & $4.13(.58)$ & $4.52(.44)$ & 1.368 & \\
IR & $3.76(1.0)$ & $3.71(.88)$ & $4.15(.67)$ & $3.80(.46)$ & $4.22(.45)$ & $4.12(.71)$ & 1.820 & \\
LA & $4.23(.41)$ & $4.11(.62)$ & $4.27(.55)$ & $4.15(.43)$ & $4.30(.33)$ & $4.47(.37)$ & 0.840 & \\
\hline
\end{tabular}

Note. CD: Course design, IS: Instructional strategy, TU: Technology usage, CM: Classroom management, IR: Interpersonal relation, LA: Learning assessment.

Academic rank and faculty teaching efficacy. The results of Table 9 shows there were statistical difference between these academic rank and faculty teaching efficacy at the USSH-VNUHCM in technology usage $(F=0.049, p<0.05)$. The finding post hoc 
comparison shows that faculty of teaching assistant rank $(M=4.24, S D=0.53)$ had more satisfied than those lecturer position $(M=3.91, S D=0.58)$. There were no significant differences between academic rank and faculty members' sense of teaching efficacy in course design, instructional strategy, classroom management, interpersonal relation, and learning assessment. The finding of this study was not supported by previous researches; however, Mehdinezhad (2012) shows that assistant professors $(M=4.06, S D=0.76)$ had higher score than associate and full professors $(M=3.58, S D=1.01)$ on teaching efficacy of learning environment.

Table 9. The results of ANOVA between academic rank and faculty teaching efficacy

\begin{tabular}{lccccc}
\hline \multirow{1}{*}{ Factors } & $\begin{array}{c}\text { Main } \\
\text { lecturer }\end{array}$ & Lecturer & $\begin{array}{c}\text { Teaching } \\
\text { assistant }\end{array}$ & $F$ & Post hoc \\
\cline { 2 - 5 } & $M(S D)$ & $M(S D)$ & $M(S D)$ & & \\
\hline Course design & $4.72(.32)$ & $4.34(.58)$ & $4.32(.54)$ & 1.732 & \\
Instructional strategy & $4.43(.39)$ & $4.10(.70)$ & $4.20(.50)$ & 1.006 & \\
Technology usage & $3.85(.71)$ & $3.91(.58)$ & $4.24(.53)$ & $0.049 *$ & TA $>$ Lr \\
Classroom management & $4.62(.41)$ & $4.27(.53)$ & $4.15(.51)$ & 2.336 & \\
Interpersonal relation & $4.25(.68)$ & $3.89(.77)$ & $3.76(.80)$ & 1.193 & \\
Learning assessment & $4.50(.35)$ & $4.20(.59)$ & $4.08(.31)$ & 1.762 & \\
\hline
\end{tabular}

Note. TA: Teaching assistant, Lr: Lecturer. The mean difference is significant at the ${ }^{*} p<.05$

Educational attainment and faculty teaching efficacy. As showed in Table 10, there were statistical difference between these educational attainment and faculty teaching efficacy at the USSH-VNUHCM in technology usage $(F=5.009, p<0.01)$. The finding post hoc comparison show that faculty members holding bachelors' degree $(M=4.32, S D=0.37)$ have higher scores in technology usage than those holding masters' degree $(M=3.88, S D=0.61)$. The same academic rank, there were no significant differences between educational attainment and faculty teaching efficacy in course design, instructional strategy, classroom management, interpersonal relation, and learning assessment. 
Table 10. The results of ANOVA between educational attainment and faculty teaching efficacy

\begin{tabular}{lcccccc}
\hline \multirow{2}{*}{ Factors } & $\begin{array}{c}\text { Doctoral } \\
\text { degree }\end{array}$ & $\begin{array}{c}\text { Masters' } \\
\text { degree }\end{array}$ & $\begin{array}{c}\text { Bachelor } \\
\text { s' degree }\end{array}$ & $F$ & Post hoc \\
\cline { 2 - 5 } & $M(S D)$ & $M(S D)$ & $M(S D)$ & & \\
\hline Course design & $4.58(.43)$ & $4.31(.60)$ & $4.42(.45)$ & 1.409 & \\
Instructional strategy & $4.40(.44)$ & $4.08(.71)$ & $4.23(.44)$ & 1.627 & \\
Technology usage & $3.97(.48)$ & $3.88(.61)$ & $4.32(.37)$ & $5.009 * *$ & B.A $>$ MA \\
Classroom management & $4.45(.38)$ & $4.25(.56)$ & $4.30(.50)$ & 0.827 & \\
Interpersonal relation & $4.05(.59)$ & $3.86(.79)$ & $3.95(.81)$ & 0.415 & \\
Learning assessment & $4.38(.42)$ & $4.17(.59)$ & $4.20(.30)$ & 0.876 & \\
\hline
\end{tabular}

Note. The mean difference is significant at the ${ }^{*} p<.01$

Unfortunately, the studies of the relationship between faculty teaching efficacy and demography factors are very few in order to discuss with the results of this study. Further research about the relationship between faculty teaching efficacy and demography factors will contribute to fill in the literature gap.

\section{Conclusion}

Teaching efficacy of faculty members in higher education have a positive influence on teaching performance and students' learning achievement. Faculty members with a high sense of efficacy tend to exhibit greater levels of planning, organization, enthusiasm, spend more time teaching in areas, more open to new ideas, more committed to teaching, and more willing to experiment with new methods.

The purpose of this study was to investigate university faculty members' perceptions of teaching efficacy in Vietnamese higher education and their relation to faculty members' demography. The results showed that the most faculty members were highly measured with their teaching efficacy; however, there is still much room for university administrators to improve the teaching efficacy level of faculty members in Vietnamese higher education. This study has also demonstrated some significant differences for faculty teaching efficacy and their demography factors. Almost demography factors, except length of employment factor, of gender, marital status, age groups, academic rank, and educational attainment were significant differences in faculty teaching efficacy. Hence, when university managers and policy makers want to improve a universal intervention to enhance faculty teaching efficacy, they should be notably concerned about both these factors.

It is encourages future researcher to study about what teachers believe to be their capability in some dimensions of teaching, research, and community service which are their tasks. The link between faculty teaching efficacy and other factors could be confirmed by direct observation in future studies. It is hoped that the barrier to the teaching efficacy of faculty members are found in this study may be useful for university management to develop work 
environment and culture that would allow higher levels of faculty teaching efficacy and can contribute to a great extent to improve the level of faculty members in Vietnamese higher education.

\section{Acknowledgment}

I would like to acknowledge my sincere gratitude to anonymous, kindest support and help, valuable advice, synthesized comments on revision, and detailed editing throughout.

\section{References}

Allinder, R. M. (1994). The relationship between efficacy and the instructional practices of special education teachers and consultants. Teacher Education and Special Education, 17(2), 86-95. https://doi.org/10.1177/088840649401700203

Ashton, P. T., \& Webb, R. B. (1986). Making a difference: Teachers' sense of efficacy and student achievement. White Plains, NY: Longman.

Bandura, A. (1986). Social foundations of thought and action: A social cognitive theory. Englewood Cliffs, NJ: Prentice-Hall.

Bandura, A. (1997). Self-efficacy: The exercise of control. New York: Freeman.

Brown, G. (1993). Effective teaching. In R. Ellis (Ed.) Quality assurance for university teaching (pp. 211-232). Bristol, PA: Open University Press.

Chang, T. S., McKeachie, W., \& Lin, Y. G. (2010). Faculty perceptions of teaching support and teaching efficacy in Taiwan. Higher Education, 59, 207-220. https://doi.org/10.1007/s10734-009-9243-8

Chang, T. S; Lin, H. H; \& Song, M. M. (2011). University faculty members' perceptions of their teaching efficacy. Innovations in Education and Teaching International, 48(1), 49-60. https://doi.org/10.1080/14703297.2010.543770

Cook, P. (1998). The influence of organizational characteristics of faculty teaching self-efficacy (unpublished doctoral dissertation). Vanderbilt University. Nashville, Tennessee.

Dillman, D. A. (2000). Mail and internet surveys: The tailored design method. New York: John Wiley and Son.

Gibson, S. \& Dembo, M., (1984). Teacher efficacy: A construct validation. Journal of Educational Psychology 76(4), 569-582. https://doi.org/10.1037/0022-0663.76.4.569

Goddard, R. D., Hoy, W. K., \& Woolfolk Hoy, W. (2000). Collective teacher efficacy: Its meaning measure,and impact on student achievement. American Educational Research Journal, 37(2), 479-507. https://doi.org/10.3102/00028312037002479

Gonyea, R. M. (2005). Self-reported data in institutional research: Review and recommendations. In P. D. Umbach (Ed.), Servey research: Emerging issues (pp. 73-89). San Francisco, CA: Jossey-Bass. https://doi.org/10.1002/ir.156 
Gow, L., \& Kember, D. (1993). Conceptions of teaching and their relationship to student learning. The British Journal of Educational Psychology, 63, 20-33. https://doi.org/10.1111/j.2044-8279.1993.tb01039.x

Hair, J. F., Anderson, R. E., Tatham, R. L., \& Black, W. C. (2006). Multivariate data analysis. New Jersey: Prentice Hall.

Johnson, S., Cooper, C.L., Cartwright, S., Donald, I., Taylor, P., \& Millet, C. (2005). The experience of work-related stress across occupations. Journal of Managerial Psychology, 20, 179-187. https://doi.org/10.1108/02683940510579803

Lin, H. L., \& Gorrell, J. (2001). Exploratory analysis of pre-service teacher efficacy in Taiwan. Teaching and Teacher Education, 17(5), 623-635. https://doi.org/10.1016/S0742-051X(01)00018-X

Malaney, G. D. (2002). You still need high response rates with web-based surveys. Student Affairs On-Line, 3(1).

Mehdinezhad, V. (2012). Faculty members' understanding of teaching efficacy criteria. Education Inquiry, 3(1), 49-69. https://doi.org/10.3402/edui.v3i1.22013

Norton, L., Richardson, J., Hartley, J., Newstead, S., \& Mayes, J. (2005). Teachers' beliefs and intentions concerning teaching in higher education. Higher Education, 50(4), 537-571. https://doi.org/10.1007/s10734-004-6363-z

Nunnally, J. C. (1978). Psychometric theory (2 ${ }^{\text {rd }}$ Ed.). New York: McGraw-Hill.

Paneque, O. M., \& Barbetta, P. M. (2006). A study of teacher efficacy of special education teachers of English language learners with disabilities. Bilingual Research Journal: The Journal of the National Association for Bilingual Education, 30(1), 171-193. https://doi.org/10.1080/15235882.2006.10162871

Ross, J. A. (1994). Beliefs that make a difference: The origins and impacts of teacher efficacy. Paper presented at the annual meeting of the Canadian Association for Curriculum Studies.

Tschannen-Moran, M., \& Woolfolk Hoy, A. (2001). Teacher efficacy: Capturing an elusive construct. Teaching and Teacher Education, 17, 783-805. https://doi.org/10.3102/00346543068002202

Tschannen-Moran, M., \& Woolfolk Hoy, A. (2002). The influence of resources and support on teachers' efficacy beliefs. Paper presented at the annual meeting of the American Educational Research Association, New Orleans, LA.

Tschannen-Moran, M., Woolfolk Hoy, A., \& Hoy, W. K. (1998). Teacher efficacy: Its meaning and measure. Review of Education Research, 68(2), 202-248. https://doi.org/10.3102/00346543068002202

Veldman, I., Tartwijk, J. V., Brekelmans, M., \& Wubbels, T. (2013). Job satisfaction and teacher-student relationships across the teaching career: Four case studies. Teaching and Teacher Education, 32, 55-65. https://doi.org/10.1016/j.tate.2013.01.005 


\section{Macrothink}

Journal of Studies in Education

ISSN 2162-6952 2017, Vol. 7, No. 1

Voluntary Service Oversea (VSO). (2002). What makes teachers tick: a policy research report on teachers' motivation in developing countries. London, VSO.

Woolfolk Hoy, A. (2004). Self-efficacy in college teaching. Essays on Teaching Excellence: Toward the Best in the Academy, 15(7), 8-11. Fort Collins, CO: The POD Network. 